Annals of Tropical Research 29[1]:73-89(2007)

(C)LU, Leyte, Philippines

\title{
Chemical dynamics of a highly weathered soil under native tree species in Mt. Pangasugan, Leyte
}

\author{
Juvia P. Sueta, Victor B. Asio, and Anabella B. Tulin \\ Department of Agronomy and Soil Science, College of Agriculture, \\ Leyte State Unversity, Baybay, Leyte 6521-A, Philippines
}

\begin{abstract}
The study evaluated the changes of the chemical properties of a highly weathered soil planted to native tree species. Soil samples were gathered at monthly interval for 12 months and were analyzed for $\mathrm{pH}, \mathrm{OM}, \mathrm{N}, \mathrm{P}, \mathrm{Ca}$ and $\mathrm{Mg}$. Decomposition of leaf litter of the dominant native tree species (Parashorea malaanonan and Dipterocarpus warburgii) in the site was determined using the litter bag method.

Results revealed significant temporal variations of $\mathrm{pH}$ in $\mathrm{CaCl}_{2}, \mathrm{OM}$, total $\mathrm{N}$ and available $\mathrm{P}$, but not for $\mathrm{pH}$ in $\mathrm{H}_{2} \mathrm{O}$ and exchangeable $\mathrm{Ca}$ and $\mathrm{Mg}$. Significant differences between sites (spatial variation) were also observed for $\mathrm{OM}$, total $\mathrm{N}$ and exchangeable $\mathrm{Ca}$ and $\mathrm{Mg}$ suggesting the important effects of vegetation type on these soil properties. Decomposition rates of $0.0331 \mathrm{~kg} / \mathrm{ha} /$ week and $0.0231 \mathrm{~kg} / \mathrm{ha} /$ week were obtained for $D$. warburgii and $P$. malaanonan, respectively. Both rates suggest fast litter decomposition.
\end{abstract}

Keywords: chemical soil dynamics, highly weathered soil, native tree species, Mt. Pangasugan, Leyte

Correspondence: J. P. Sueta Address: Department of Agronomy and Soil Science, College of Agriculture, Leyte State University, Baybay, Leyte, 6521-A, Philippines. Tel. No. (053) 3352627

DOI: $10.32945 /$ atr2916.2007 


\section{INTRODUCTION}

Highly weathered soils of the humid tropics are characterized by high leaching and acidity (Hassett and Banwart, 1992). They also have high clay content and abundant stable secondary minerals like halloysite or kaolinite and thus are generally less productive and difficult to manage (Sanchez, 1976).

In Southeast Asia, more than $1 / 3$ of the total area is covered by infertile highly weathered soils classified as Ultisols and Oxisols in the USDA Soil Taxonomy (Soil Survey Staff, 1996) or Acrisols and Ferralsols in the World Reference Base (WRB) (IUSS Working Group WRB, 2006). In the Philippines, about $58 \%$ of the total land area has acidic soil conditions (Stark, 2000). In the mountainous areas of Leyte, many soils are highly weathered and can be classified as Ultisols (Asio, 1996; Asio et al., 1998). Studies indicated that nutrients are generally limited in these highly weathered ultisols (Jahn and Asio, 1998; Zikeli et al., 2000).

Trees generally influence the soil chemical properties with time by providing the soil with organic matter mainly in the form of leaf litter accumulated in the thin A and O horizons. Trees could survive for many years, thus contributing considerable amount of leaf fall to the soil surface. Upon decomposition, the chemical components of this litter are released back to the soil. This, in fact, is the major recognized avenue by which trees add organic matter to the soil (Altieri, 1987). Nutrient enrichment by some tree species enables highly weathered and infertile soil types to support vegetation growth. Individual tree species also affect the chemical properties of the soil in their vicinity. Properties such as stem flow and litter accumulation could be important in their effects on soil properties as processes associated with the different species (Riha et al., 1986).

While it is widely accepted that trees play a major role in nutrient enrichment of the soil underneath them, there is very little information available on the effects of the different tree species on the chemical properties of a highly weathered soil under a humid tropical island environment. For native tree species, the lack of published literature on their performance on reforestation could be one reason why they are not commonly used (Langenberger, 2000).

To achieve better understanding of the important role of trees in improving soil quality, it is important to understand how nutrient availability changes with time (Kelly and Mays, 1999). Although much research has been done on the 
characteristics of highly weathered soils, there is little available information on the changes of their chemical properties following a change in land use, particularly from Imperata grassland to plantation of indigenous tree species. In particular, very little data exist on the nature and rate of change of soil chemical properties under native tree species.

This study was conducted to evaluate the dynamics of some chemical properties of a highly weathered soil as influenced by native tree species.

\section{MATERIALS AND METHODS}

\section{Study site}

The study site is located at the GTZ Reforestation Site (Closed Canopy Project) on the lower western slope of Mt. Pangasugan at an elevation of approximately $100 \mathrm{~m}$ above sea level. Original vegetation was dipterocarp forest (Langenberger et al., 2005) which was replaced with Imperata cylindrica until the early 1990's as a result of shifting cultivation. In 1994, native tree species were planted which now cover the area. Table 1 summarizes the dominant tree species found at the two sites selected.

\section{Collection and preparation of soil samples}

Three sampling plots measuring $3 \mathrm{~m} \times 4 \mathrm{~m}$ were established at two neighboring areas inside the reforestation project site. From each plot, six subsampling points were marked. Soil samples were collected around each point at $20 \mathrm{~cm}$ depth using a soil auger at monthly interval for $12 \mathrm{months}$. The subsamples were mixed thoroughly to obtain one composite sample for each plot. In the same manner, a composite sample was also collected from a nearby area covered with grasses (P. conjugatum) for comparison purposes. The area has been in existence for more than 10 years now.

Right after sampling, the collected samples were air-dried, freed of large plant residues and rock fragments, and then ground using a wooden mallet and allowed to pass through a 2-mm wire mesh. This fine-earth fraction was the sample used for most analyses. For organic matter (OM) analysis, enough amount of fine-earth fraction was taken and then ground again until all particles passed through a $0.0425 \mathrm{~mm}$ sieved. The samples were then stored in plastic containers ready for analysis. 
Table 1. Dominant native tree species found in the two adjacent sampling sites in

\begin{tabular}{lll}
\multicolumn{2}{c}{ Mt. Pangasugan, Leyte } & \\
\hline Site & Common Name & Scientific Name \\
\hline 1 (lower slope) & Bagtikan* & Parashorea malaanonan \\
& Mayapis & Shorea palosapis \\
& Dao & Dracontomelon dao \\
& Almaciga & Agathis philippinensis \\
2 (upper slope) & Hagakhak* & Dipterocarpus warburgii \\
& White lauan & Shorea pentacme \\
& Yakal-saplungan & Hopea plagata \\
& Almaciga & Agathis philippinensis \\
& Antipolo & Artocarpus blancoi \\
\hline
\end{tabular}

* Most common

\section{Analysis of soil chemical properties}

Soil $\mathrm{pH}$ was measured potentiometrically in water and in $0.01 \mathrm{M}$ $\mathrm{CaC}_{12}$ at a soil-solution ratio of 1:2.5 (ISRIC, 1995). OM was determined following the Walkey-Black method (ISRIC, 1995). Total N was determined by the modified Kjeldahl method of ISRIC (1995). Available Pwas extracted using the Bray No. 2 method of Jackson (1958), by the method of Murphy and Riley (1962) for color development, and by spectrophotometry for quantification. Exchangeable $\mathrm{Ca}$ and $\mathrm{Mg}$ were determined by titration with EDTA using $\mathrm{NaNO}_{3}$ as extractant (PCARR, 1980).

\section{Rate of litter decomposition}

Native tree species and associated vegetation in the two sites were identified with the assistance of a vegetation specialist. The leaf litter of two dominant tree species at each site, Parashorea malaanonan Brandis (bagtikan) and Dipterocarpus warburgii (hagakhak), were then used for the decomposition study. Litter decomposition was studied using the litter bag method (Verhoef, 1995).

Fresh leaf litter of the above-mentioned tree species were collected, washed, and oven-dried at $40^{\circ} \mathrm{C}$ until a constant weight was obtained. Two grams of leaf litter was weighed, cut into small pieces and placed in separate 7 x $10 \mathrm{~cm}$ litterbags made from $1 \mathrm{~mm}$ nylon mesh. Thirty samples (bags) were used for each tree species. The bags were placed randomly on the soil surface and covered lightly with leaf litter. Collection of litterbags was done after 3 
weeks and at 3-weeks interval thereafter, with five samples taken from each site. The litter remaining inside each litterbag was air-dried, brushed lightly to remove adhering soil particles, and then oven-dried again at $40^{\circ} \mathrm{C}$ until constant weight was reached. The final weights were used to compute for the percentage loss of weight as index of decomposition. The actual rates of decomposition were computed using the equation derived from the Weigart and Evans' equation (Cuevas and Sajise, 1978) for the instantaneous rate of decay, as follows:

$$
r=\frac{\Sigma \mathrm{t} 2}{\Sigma \mathrm{Yt}}
$$

where: $\mathrm{Y}=1 \mathrm{n} \mathrm{Wo} / W t$

Wo $=$ initial dry weight of litter $(2 \mathrm{~g})$

$\mathrm{Wt}=$ dry weight after a period of time

$\mathrm{t}=$ time in weeks

Analysis of data

All data for chemical soil properties were analyzed using standard ANOVA to determine significant variations with time and with site.

\section{RESULTS AND DISCUSSION}

\section{General characteristics of the soil}

Early pedological studies conducted in the study site (Asio, 1996) showed that the soil was developed from late Pleistocene to Miocene andesitic pyroclastic rocks. The typical soil color ranges from dark brown (7.5 YR 3/ $3)$ on the surface to yellowish red (5YR 4/6) in the lower horizons. The general horizon sequence is $\mathrm{Ah}-\mathrm{BA}-\mathrm{Bt}-\mathrm{BC}$. The soil is friable when moist due to very good aggregation but exhibits plasticity and stickiness when wet. The soil is relatively acidic with a $\mathrm{pH}$ value of less than 5.00, an effective CEC of 7.84 to $9.17 \mathrm{cmol}(+) / \mathrm{kg}$, base saturation of less than 30 percent, and a very low available $\mathrm{P}$ due to a high phosphate retention capacity of more than 96 percent. 
The highly weathered nature of the soil is also shown by the dominance of 1:1 clay minerals such as halloysites and kaolinites, and iron oxides like goethite and hematite (Jahn and Asio, 1995). The soil is classified as a Haplic Alfisol (FAO, 1988) or a Hapliudult in the USDA Soil Taxonomy (Soil Survey Staff, 1992).

\section{Dynamics of soil chemical properties}

Significant monthly changes were observed on soil $\mathrm{pH}$ in $0.01 \mathrm{M}$ $\mathrm{CaCl}_{2}$ but not on the $\mathrm{pH}$ in water (Table 2). However, no significant difference in the values of both $\mathrm{pH}$ measurements between the sites was found. Results also showed irregular trend for $\mathrm{pH}$ in water (Figure 1a) and a slightly increasing trend for $\mathrm{pH}$ in $0.01 \mathrm{M} \mathrm{CaCl}_{2}$ (Fig. 1b). Soil $\mathrm{pH}$ in water ranged from 4.77 to 5.17 while in $\mathrm{CaCl}_{2}$ it ranged from 4.30 to 4.90 indicating higher $\mathrm{pH}$ values of the former than the latter method (Asio et al., 1992). A slightly increasing trend of $\mathrm{pH}$ in $0.01 \mathrm{M} \mathrm{CaCl}_{2}$ could be attributed to the possible effect of $\mathrm{Ca}$ and $\mathrm{Mg}$ from mineral weathering in the upper slope of the area and probably to the release of nutrients from leaf litter decomposition.

Bache (1988) found that $\mathrm{pH}$ in $0.01 \mathrm{M} \mathrm{CaCl}_{2}$ is more stable than $\mathrm{pH}$ in water primarily because the former limits suspension and stirring effects. The use of $0.01 \mathrm{M} \mathrm{CaCl}_{2}$ can also effectively mask small differences in salt concentration. Schlichting et al. (1995) also pointed out that $\mathrm{Ca}$ and $\mathrm{K}$ ions are able to replace weakly adsorbed $\mathrm{H}$ - and $\mathrm{Al}$-ions which is not possible in the case of water. This could partly explain why significant results were obtained for $\mathrm{pH}$ in $0.01 \mathrm{M} \mathrm{CaCl}_{2}$ but not for $\mathrm{pH}$ in water and consequently a higher $\mathrm{CV}$ for $\mathrm{pH}$ in water than in $0.01 \mathrm{M} \mathrm{CaCl}_{2}$ (Table 2).

Irregular fluctuations in $\mathrm{pH}$ values could be explained by the fact that soil $\mathrm{pH}$ is a very changeable soil property. It is strongly affected by processes such as organic matter decomposition, pedoturbation, weathering, leaching and decomposition. At any given time, $\mathrm{H}+$ inputs to the soil could vary. In general, $\mathrm{pH}$ dynamics in the soil reflects the interaction of vegetation, organisms, and various other processes (Magdoff et al., 1987).

Changes in OM content are significant both with time (months) and between sites (Table 2). The variations were irregular and appeared to have no clear trend (Fig. 2a). The figure also shows that the upper slope had slightly higher OM content than the lower slope while the grassland area had the lowest. The lower OM levels in the grassland soil is probably the result of 
Table 2. Summary of the ANOVA results for the dynamics of some soil chemical properties

\begin{tabular}{|c|c|c|c|c|c|c|c|}
\hline \multirow[b]{2}{*}{ Variation } & \multicolumn{7}{|c|}{ Soil Chemical Properties } \\
\hline & $\begin{array}{l}\mathrm{pH} \\
\mathrm{H}_{2} \mathrm{O}\end{array}$ & $\begin{array}{l}\mathrm{pH} \\
0.01 \mathrm{M} \\
\mathrm{CaCl}_{2}\end{array}$ & $\mathrm{OM}$ & $\begin{array}{l}\text { Total } \\
\mathrm{N}\end{array}$ & $\begin{array}{l}\text { Avail. } \\
\text { P }\end{array}$ & $\begin{array}{l}\text { Exch. } \\
\mathrm{Ca}\end{array}$ & $\begin{array}{l}\text { Exch. } \\
\mathrm{Mg}\end{array}$ \\
\hline $\begin{array}{l}\text { 1. Temporal } \\
\text { (between } \\
\text { months) }\end{array}$ & ns & $* *$ & $* *$ & * & $* *$ & ns & $\mathrm{ns}$ \\
\hline $\begin{array}{l}\text { 2. Spatial } \\
\text { (between sites) }\end{array}$ & ns & ns & ** & $* *$ & $\mathrm{~ns}$ & $*$ & $* *$ \\
\hline C. V. \% & 7.49 & 1.37 & 8.79 & 7.88 & 35.85 & 6.16 & 8.73 \\
\hline
\end{tabular}

lower litter production and better mineralization relative to soils under trees or plants. It should be pointed out, however, that this grassland studied is dominated by a single grass species (P. conjugatum).

Generally, OM dynamics in the soil is a function of the addition and losses of organic material in the soil (Sanchez, 1976). The amount of OM accumulated in the soil depends on the litterfall contributed by trees as the primary vegetation in the area and the consequent decomposition of these materials. The higher amount of OM for site 2 could probably be due to greater litterfall since this site has larger trees and thicker canopy.

Stevenson (1982) emphasized that for forest soils, differences in the profile distribution of OM and similarly N, occur by virtue of the manner in which leaf litter becomes mixed with mineral matter. The irregular fluctuations in OM values through time could be attributed to the complex effects of the time of the year, soil and crop management practices (McGill et al., 1986) rainfall, temperature and soil texture (Parton et al., 1987) as well as the amount of C incorporated into the soil (Rasmussen and Collins, 1991) which is much a function of the organic residues returned to the soil as litterfall.

Results also showed significant monthly changes in the total $\mathrm{N}$ content of the soil. Variations between sites were also significant (Table 2). Since about 95 percent of the soil $\mathrm{N}$ is present in organic matter (Pagel et al., 1982), the trend for total $\mathrm{N}$ is closely similar to that of OM. Figure $2 \mathrm{~b}$ shows short-term fluctuations of the total $\mathrm{N}$ content of the soil. These fluctuations could be 


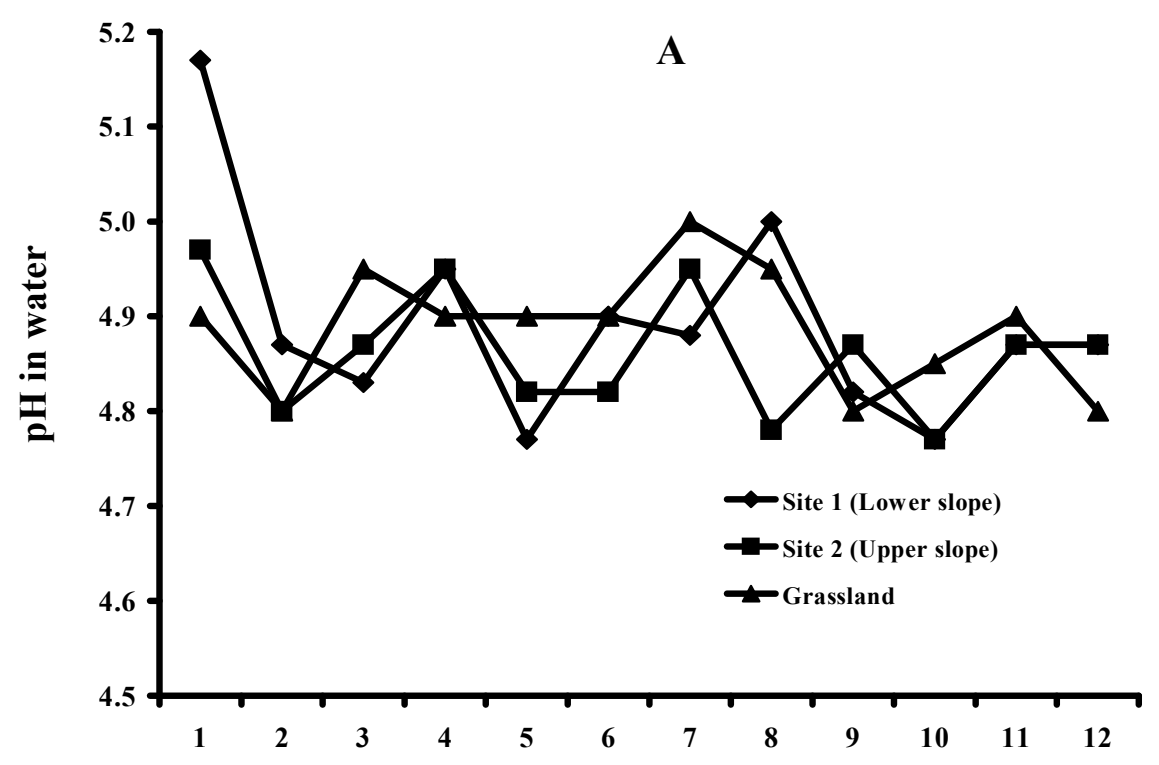

Time (months)

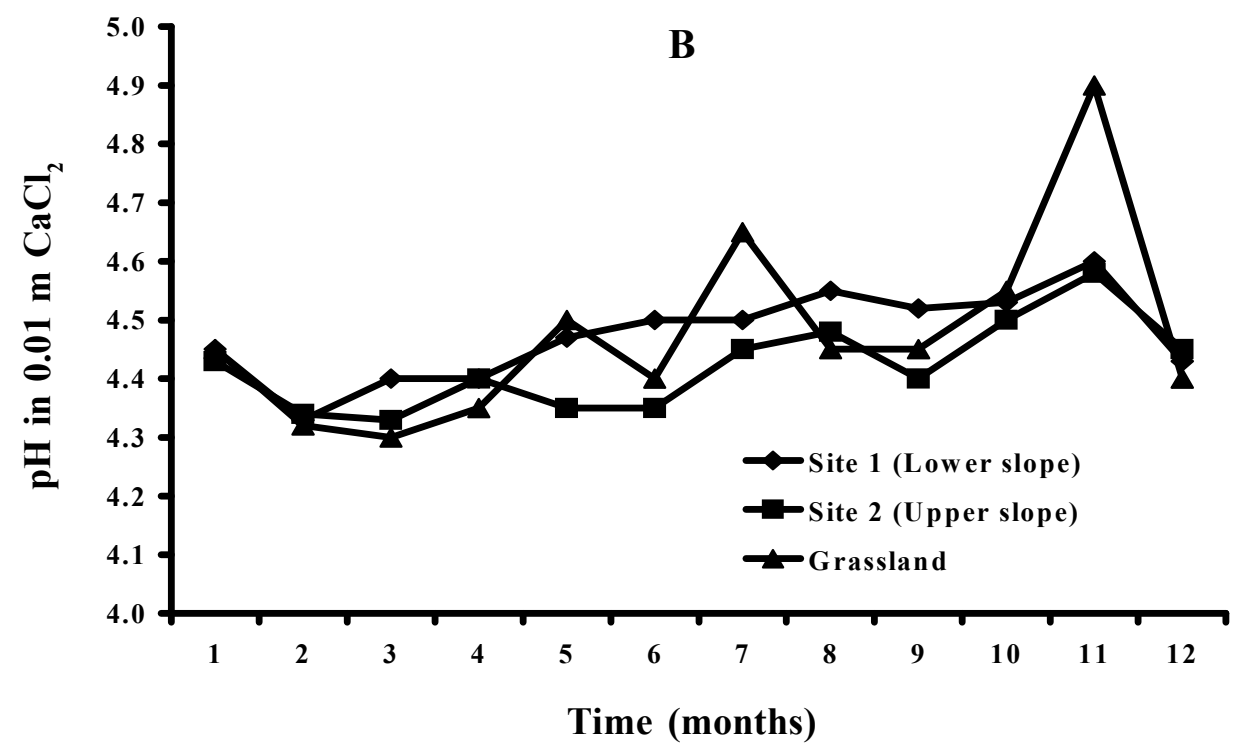

Figure 1. Dynamics of $\mathrm{pH}$ in water (a) and $\mathrm{pH}$ in $\mathrm{CaCl}_{2}$ of a highly weathered soil under native tree species in Mt. Pangasugan, Leyte (November 2001-October 2002) 
A
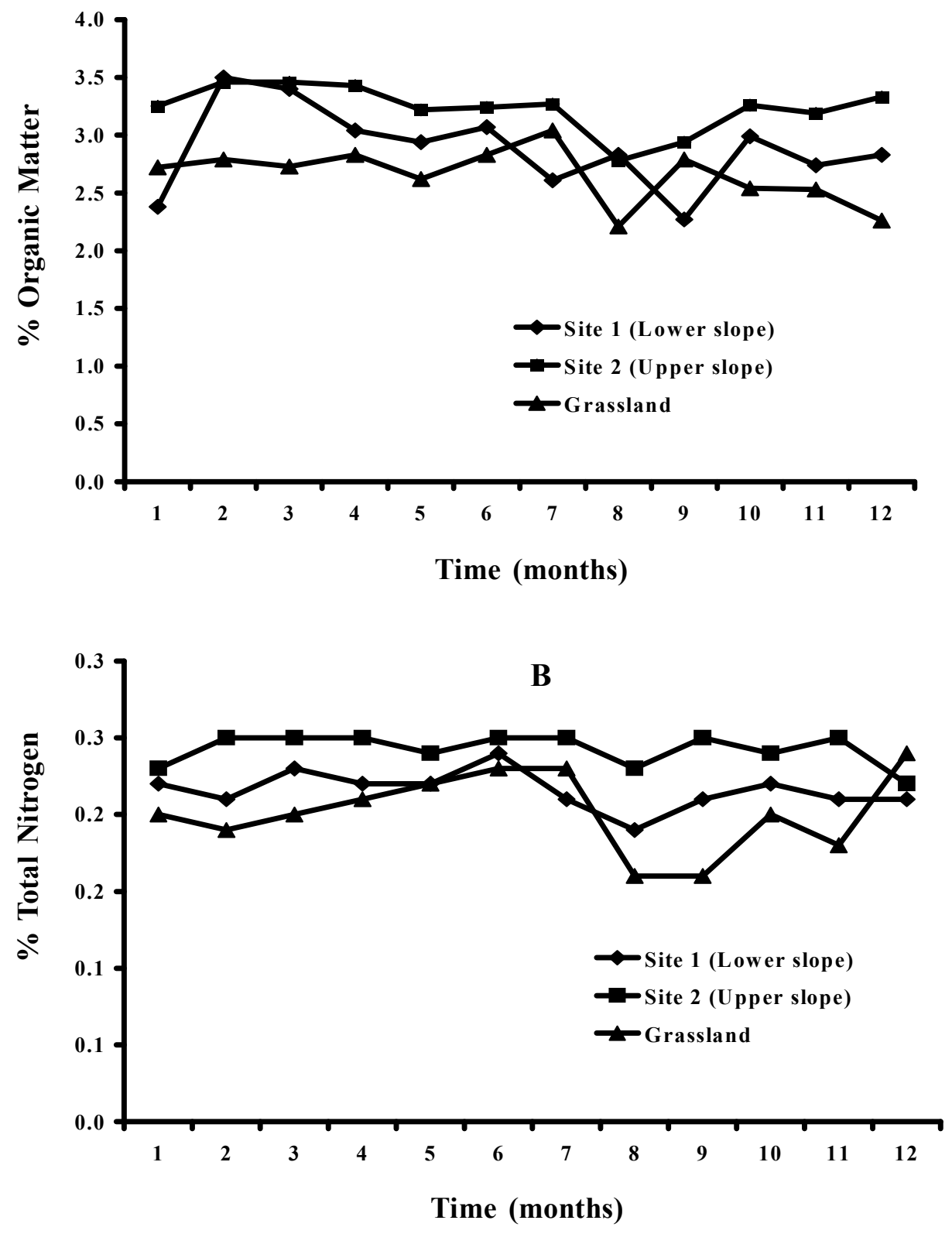

Figure 2. Dynamics of organic matter (a) and total nitrogen (b) of a highly weathered soil under native tree species in Mt. Pangasugan, Leyte (November 2001-October 2002) 
attributed to the extent of the mineralization and immobilization processes in the soil. These two processes ultimately control the amount of $\mathrm{N}$ in the soil. Roth (1996) pointed out that $\mathrm{N}$ dynamics in the soil is complex since it is affected by and interacts with a spectrum of processes ranging from the mineral composition and chemical milieu of the soil to the flow of water and the dynamics of microorganisms and plant roots.

Concerning $\mathrm{P}$, significant monthly changes in its available amount in the soil within plots were observed but not between sites (Table 2). Figure 3 shows these significant short-term fluctuations. The decrease can be due to uptake by plants while the increases can be due to enhanced decomposition and weathering or improved soil $\mathrm{pH}$ although the values are still considered deficient (Landon, 1991).

Despite the low levels of $\mathrm{P}$, however, native trees could still survive in the area. Primarily because of outside sources of P coming from rainfall (Zikeli et $a l ., 2002)$, the roots ability to produce weak organic acids that enhance weathering of rocks or mineral fragments, and other adaptive mechanisms inherent to these species, they have an advantage over exotic species.

Results showed no significant variations in exchangeable $\mathrm{Ca}$ and $\mathrm{Mg}$ with time (Table 2) indicating that the amount of losses due to leaching and nutrient uptake is probably balanced by the release from litter decomposition and mineral weathering. Variations in the amount of exchangeable $\mathrm{Ca}$ and $\mathrm{Mg}$ are shown in Figure 4 . The fast litter decomposition probably helps maintain the relatively sufficient levels of $\mathrm{Ca}$ and $\mathrm{Mg}$ in the soil surface. This indicates a possible improvement of the nutrient status of the surface soil due to the nutrient cycling effect of the tree vegetation.

\section{Litter decomposition}

Through time, trees can transform the nature of the upper soil horizon through the thick deposition of litterfall (Huxley, 1999). In Mt. Pangasugan, a few centimeters thick of horizon composed of partly decomposed plant materials and fresh litter can be observed on the soil surface. Since litter decomposition greatly affects the chemical and nutrient dynamics of forest soils, a litter decomposition study was also done. Results revealed generally fast decomposition rates for the two indigenous species (Parashorea malaanonan and Dipterocarpus warburgii). Although the decomposition 


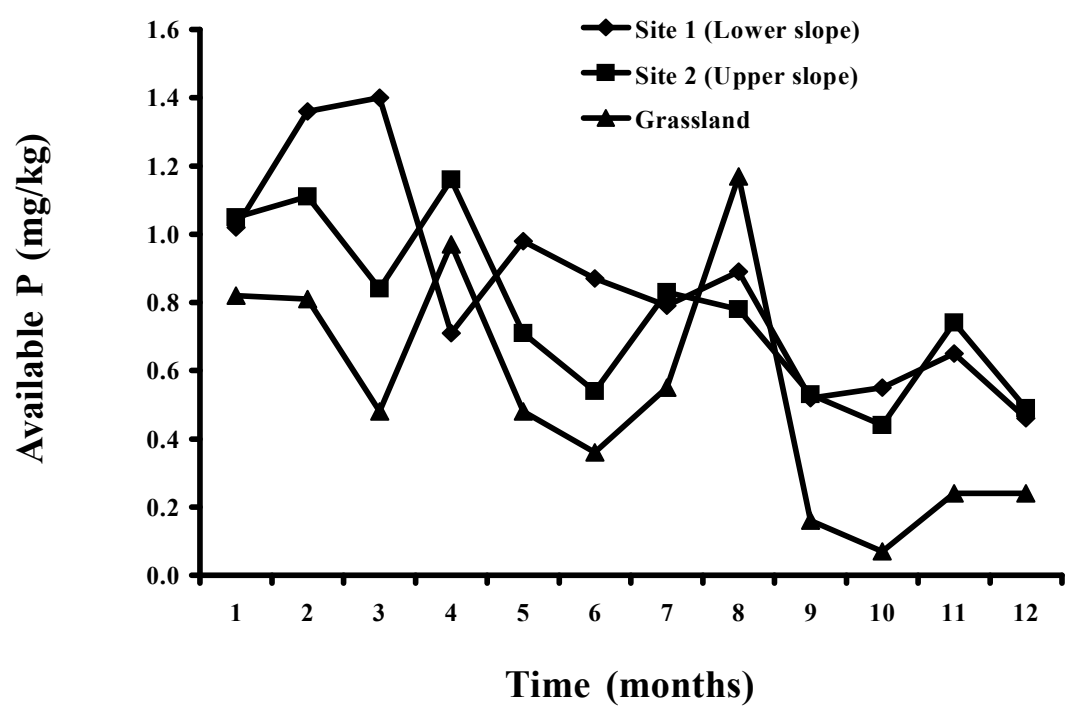

Figure 3. Dynamics of available $P$ of a highly weathered soil under native tree species in Mt. Pangasugan, Leyte (November 2001- October 2002) 


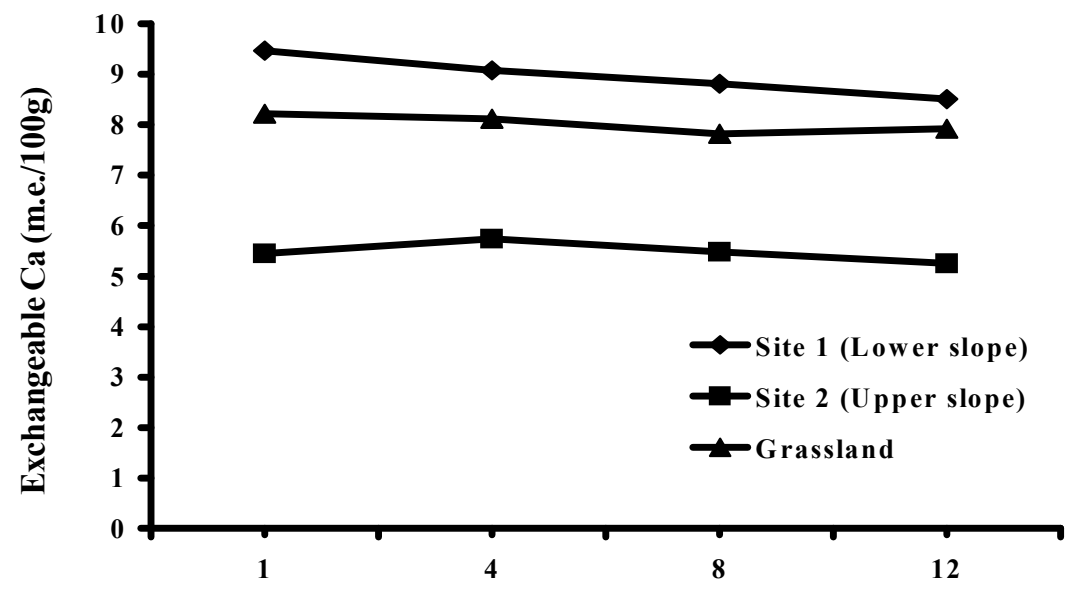

Time(months)

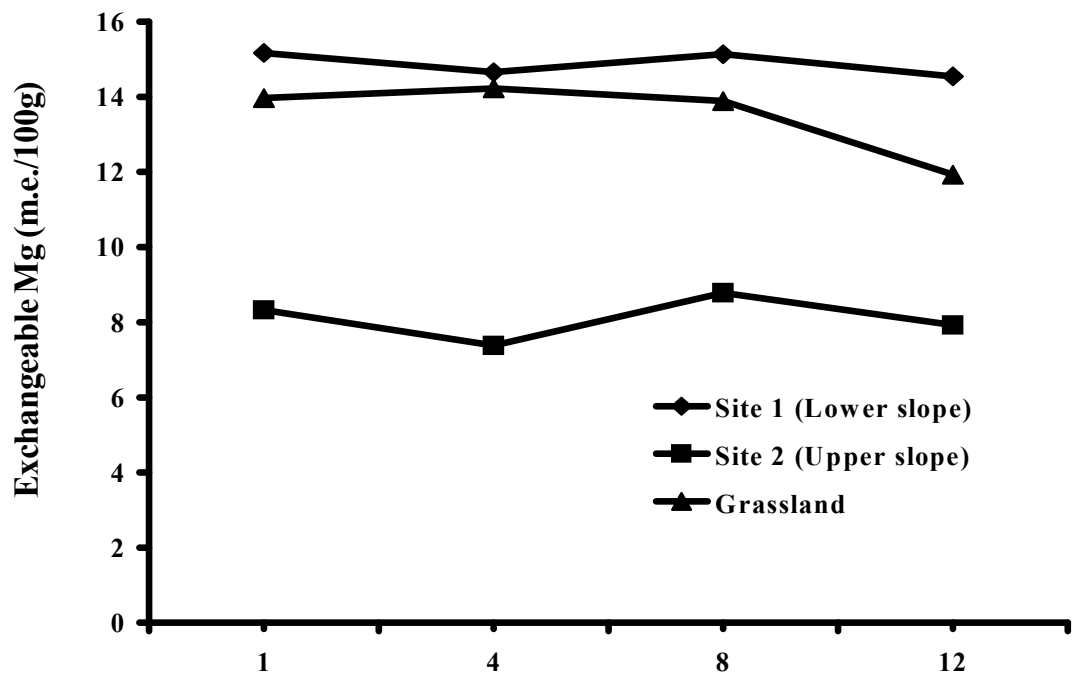

Time (months)

Figure 4. Dynamics of exchangeable $\mathrm{Ca}$ and $\mathrm{Mg}$ of a highly weathered soil under native tree species in Mt. Pangasugan, Leyte (November 2001-October 2002) 


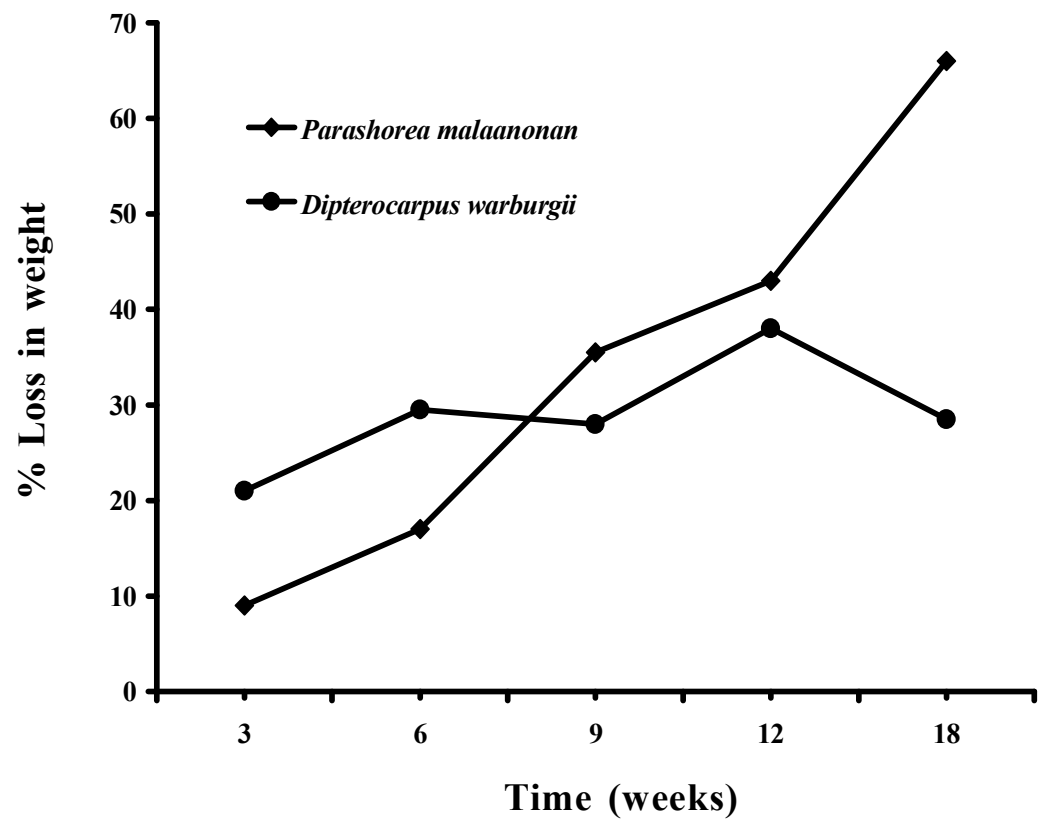

Figure 5. Percentage weight loss of Parashorea malaanonan and Dipterocarpus warburgii leaf litter after weeks of decomposition on the ground 
behavior appeared to vary between the two (Figure 5). Using the equation of Weigart \& Evans' the actual rates of decomposition (r) was $0.02311 \mathrm{~kg} / \mathrm{ha} /$ week for $P$. malaanonan and $0.0331 \mathrm{~kg} / \mathrm{ha} /$ week for $D$. warburgii. The result for $P$. malaanonan was confirmed by the study of Buenafe (2006). Cuevas and Sajise (1978) obtained an r value of $0.0342 \mathrm{~kg} / \mathrm{ha} / \mathrm{week}$ in Mt. Makiling using the equation but there was no mention of the specific species used. Manipula et al. (1999) evaluated the rate of litter decomposition in Davao del Norte and they observed that in the flatland, leaves totally decomposed after only about five months and for the hillyland, decomposition took a month more. Gapasin et al. (1993) as cited by Asio (1996), found an average of 52 percent decomposition after two months. Figure 5 shows an average weight loss of about 33.5 percent in about 9 weeks. The result of the study could only provide an estimation of the actual rate of decomposition since this could vary from one species to another, from one site to another, or due to the existing environmental conditions.

\section{CONCLUSION}

The highly weathered soil under native tree species showed significant monthly (temporal) variations in $\mathrm{pH}$ in $0.01 \mathrm{M} \mathrm{CaCl}_{2}, \mathrm{OM}$, total $\mathrm{N}$ and the spatial variations of $\mathrm{OM}$, total $\mathrm{N}$ and exchangeable $\mathrm{Ca}$ and $\mathrm{Mg}$. The native tree species in the site appear to help maintain the nutrient status of the inherently acidic and infertile highly weathered soil. The fast litter decomposition rate on the surface of the soil also appear to contribute to the improved nutrient status of the surface of the soil.

\section{ACKNOWLEDGMENT}

The authors would like to thank the Rainforestation Monitoring Project of the Institute of Tropical Ecology (LSU) funded by the GTZ-Leyte Island Program for the partial financial support.

\section{LITERATURE CITED}

ALTIERI, M. 1987. Agroecology: The Scientific Basis of Alternative Agriculture. Westview Press, USA. 227 pp. 
AMEDEE, G. and M. PEECH. 1976. Liming of highly weathered soils of the humid tropics.Soil Science. 121 [5]: 259-266

ASIO, V. B. 1996. Characteristics, weathering formation and degradation of soils form volcanic rocks in Leyte, Philippines. Hohenheimer Bodenkundliche Hefte 33. Stuttgart, Germany. 209 pp.

ASIO, V. B., R. JAHN, K. STAHR, and J. MARGRAF. 1998. Soils of the Tropical Forests of Leyte, Philippines. II. Impact of different land uses on status of organic matter and nutrient availability. In; Soils of Tropical Forest Ecosystems (A. Schulte and D. Ruhiyat, eds.) Springerverlag, Berlin-Heidelberg-New York pp. 37-44.

ASIO, V. B., R. B. ARMECIN and A. T. BAUTISTA. 1992. Relationship between exchangeable aluminum and $\mathrm{pH}$ in some acidic Philippine soils. Philippine Journal of Science 121: 383-390.

BACHE, B. 1988. Measurements and machineries in acid soils. Comm. Soils Sci. Plant Anal. 19:775-792.

BONNEAU, M. and B. SOUCHIER. 1982. Constituents and Properties of Soil. Academic Press, Ltd. London. 308 pp.

BUENAFE, H.C. 2006. Comparison of leaf litter decomposition of bagtikan (Parashorea malaanonan Brandis and mahogany (Swietenia macrophylla King) in the rainforestation site of Mt. Pangasugan. Undergrad. Thesis. Leyte State University. 44 pp.

CUEVAS, V.C. and P. E. SAJISE. 1978. Litterfall and leaf litter decomposition in a Philippine secondary forest. Kalikasan. Phil. Jour. Biol. 7[2]:99-109

FAO. 1988. Soil Map of the World. Revised Legend. World Soil Resources Report 60. $119 \mathrm{pp}$.

HASSETT, J.J. and W.L. BANWART. 1992. Soils and their Environment. Prentice Hall. Englewood Cliffs. New Jersey. 429 pp.

HUXLEY, P.A. 1999. Tropical Agroforestry. Blackwell Science, Ltd. USA. 371 pp.

International Soil Reference and Information Center. 1995. Procedures for Soil Analysis. (L.P. van Reuwijk, ed.). ISRIC. Wageningin

IUSS Working Group WRB. 2006. World Reference Base for Soil Reference (E.Micheli, P. Schad and O. Spaargen, eds.) ISRIC, Wageningen)

JACKSON, M. L. 1958. Soil Chemical Analysis. Prentice Hall, Inc. New Jersey. 498 pp.

JAHN, R. and V.B. ASIO. 1998. Soils of the Tropical Forests of Leyte, Philippines. I. Weathering, Soil Characteristics, Classification and Site Qualities. In: Soils of Tropical Forest Ecosystems: Characteristics, Ecology and Management (Schulte, A. and D. Ruhiyat, eds.) Springer-Verlag. Berlin-Heidelberg-New York. Pp 2937. 
JORDAN, C. F. 1985. Nutrient Cycling in Tropical Forest Ecosystems. John Wiley and Sons, Ltd. USA. 189 pp.

KELLY, J.M. and P.A. MAYS. 1999. Nutrient changes within a growing season in two deciduous forest soils. Soil Sci. Soc. Am. J. 63[1-3]:225

LANDON, J. R. 1991. Booker Tropical Soil Manual. Booker Tate Limited. 474 pp.

LANGENBERGER, G. 2000. Forest vegetation studies in the foothills of Mt. Pangasugan, Leyte, Philippines. TOB Publication Of-11/10e. Tropenoekologisches Begleitprogram, GTZ. Eschborn, Germany. 52 pp.

LANGENBERGER, G., K. MARTIN and J. SAUERBORN. 2005. Vascular plant species inventory of a Philippine lowland rainforest and its conservation value. Biodiversity and Conservation 15:1271-1301

MAGDOFF, F.R., R.J. BARTLETT, and D.S. ROSS. 1987. Acidification and $\mathrm{pH}$ buffering offorest soils. Soil Sci. Soc. Am. J. 51[5]:1384

MANIPULA, B.M., N.S. GIANAN, and F.D. VIRTUCIO. 1999. Culm removal effect on culm yield and biomass productivity of Laak (Bambusa sp.2) in flatland and hillyland sites in Pandapan, Tagum, Davao del Norte. The Phil. Lumberman XLV[4]:9-14

MCGILL, W.B., K.R. CANNON, J.A.ROBERTSON, and F.D. COOK. 1986. Dynamics of soil microbial biomass and water soluble organic $\mathrm{C}$ in Breton $\mathrm{L}$. after 50 years of cropping to two rotations. Can. J. Soil Sci. 66:1-9

MURPHY, J. and J.P. RILEY. 1962. Modified single solution for the determination of phosphates in natural waters. Anal. Chem. Acata 27:31-36

NAIR, P.K.R. 1984. Soil Productivity Aspects of Agroforestry. International Center for Research in Agronomy (ICRAF). Nairobi. Pp 29-39

PAGEL, H., J. ENZMANN and H. MUTSCHER. 1982. Pflanzennaerhstoffe in tropischen Boeden. VEB Deutscher Landwirtschaftsverlag, Berlin. 272 pp.

PARTON, W.J., D.S. SCHIMAL, C.V. COLE, and D.S. OJIMA. 1987. Analysis of factors controlling soil organic matter levels in Great Plains grasslands. Soil Sci. Sc. Am. J51:1173-1179

RASMUSSEN, P.E. and H.P. COLLINS. 1991. Long term impacts of tillage, fertilizer, and crop residue on soil organic matter in temperate and semi-arid regions. Advances in Agronomy 45:93-134

RIHA, S.J., B.R. SENESAC and E. PALLANT. 1986. Spatial variability of soil $\mathrm{pH}$ and organic matter in forest plantations. Soil Sci. Soc. Am. J. 50[5]:1347-1352

ROTH, K. 1996. The role of modeling and simulation in soil physical research. Zeitchrift f. Kulturtechnik and Landentwicklung. 37:32-39 
SANCHEZ, P. 1976. Properties and management of soils in the tropics. Wiley and Sons, New York, 618pp.

SCHLICHTING, E., H.P. BLUME and K. STAHR. 1995. Bodenkundliche Practicum (2. Auflage). Soil Science Practicum (2nd ed.) Blackwell, Berlin. 295 pp.

SOIL SURVEY STAFF. 1992. Keys to Soil Taxonomy. (5th ed) SMSS, Monogaph No. 19. Pocahontas Press, Blacksburg, Virginia. 556 pp.

STARK, M. 2000. Soil management strategies to sustain continuous crop production between vegetative contour strips on humid tropic hillsides. Technology development and dissemination based on farmer's adaptive field experimentation in the Philippines. ICRAF. Southeast Regional Research Programme, Bogor, Indonesia. $255 \mathrm{pp}$.

STEVEnSON, F.J. (ed.). 1982. Nitrogen in Agricultural Soils. Agronomy Series 22. ASA, CSSA, SSSA. 1-39 pp

TRUDGILL, S.T. 1977. Soils and their Environment. Prentice Hall, Inc. New Jersey. $424 \mathrm{pp}$.

VERHOEF, H. A. 1995. Litterbag method. In: Methods in Applied Soil Microbiology and Biochemistry (K. Alef and P. Nannipieri, eds.). Academic Press, London. pp: $485-487$

ZIKELI, S., V.B. ASIO and R. JAHN. 2000. Nutrient status of soils in the rainforest of Mt. Pangasugan, Leyte, Phil. Ann. Trop. Res. 22[122]:78 